\title{
Innovation of Automobile Manufacturing Technology Practice Teaching
}

\author{
Renhua Yang \\ School of Automobile and Transportation \\ Xihua University \\ Chengdu, 610039, China
}

\begin{abstract}
In order to effectively improve the automobile manufacturing process practice teaching effect, this paper analyzes the present situation of automobile manufacturing process practice teaching and summarizes the existing problems in automobile manufacturing process practice teaching, and designs the innovation mode of automobile manufacturing process practice teaching with emphasis on the problems of ' $1+1$ +1 ' and 'Trinity' automobile manufacturing process practice teaching mode. The practice teaching model can effectively solve the problem of process practice teaching.
\end{abstract}

Keywords_Practice Teaching; Innovation; Internship; Craft

\section{INTRODUCTION}

Automobile manufacturing technology practical teaching, a strong engineering technical, is an important part of professional course system and course structure of vehicle engineering. It is a significant way for students to master basic skills, apply theory to reality, analyze and solve problems, as well as improve their comprehensive quality. It also plays an important role in training and cultivating talents with innovative consciousness and innovative abilities. Automobile manufacturing technology practical teaching mainly includes two parts: Automobile manufacturing technology production practice and Automobile manufacturing technology course design. Production practice is one of important curriculum's set among vehicle engineering teaching plan, which is the process of combining basic theoretical knowledge and foundation of professional knowledge with practical application. As a student of engineering, not only have a solid foundation of theoretical knowledge, but also through the corresponding professional production department or enterprise production practice training, through the internship allows students to the professional production of the basic process, the main equipment and technology Management and other aspects of a better understanding. And course design is an effective way to improve students' capability of comprehensive knowledge application. Though much attention has widely been paid to automobile manufacturing technology practical teaching, practical teaching involves many aspects and needs more investment compared with theory course. Nowadays, there still exists many problems in it, for example relatively single practical teaching patterns, unsound evaluation system of practice teaching, imperfection of practical teaching base and et al, which are unbeneficial to cultivating students' practice ability. Thus, traditional automobile manufacturing technology practical teaching model needs innovation. This paper mainly makes a research on the innovation of automobile manufacturing technology practical teaching links.

\section{Present Situation AnAlysis For Automobile MANUFACTURING TECHNOLOGY PRACTICAL TEACHING}

\section{A. Present situation}

The main part of practice teaching of Automobile manufacturing technology is production practice, which is mainly in the process of machining technology, ninety percent of the students' time is spent in the machine shop, and ten percent of time is spent visiting the engine assembly process and automobile general factory. Generally, practice processes are as follows: inviting engineers to give lectures, understanding drawing, observing in the workshop, understanding typical equipment, process equipment and process of typical parts, noting, writing practice reports, etc. The whole process of practice mainly focus on the machining process, students do not have a good understanding of the enterprise status, the development trend of the enterprise and industry development trends, etc. Therefore, there still exist many problems in the process of practice teaching.

\section{B. The main problems at present[1][2][3]}

\section{1) Focusing on theory and ignoring practice}

From the school to the faculty leadership as well as the majority of students and teachers, most of them treat practice teaching as an attachment and supplement of theory teaching, thus contrary to the principle of unity of theory with practice, which is not compatible with today's demands of the talent cultivation. At present, the theoretical foundation of engineering students is more solid, but the ability is poor. The students lack innovative consciousness, which are the results of emphasizing theory and lighting practice too much, emphasizing knowledge and lighting ability. Due to the existing thought as above, some students do not pay enough attention to the practice, holding the attitude of indifference to the industrial practice. Those students practice without activity in the workshop, doing things carelessly, being less likely to ask questions when they have problems. When practice over, they copy others' summary and practice report. These students' internship effect can be imagined, at the same time, we also can not underestimate their influence to other students. 


\section{2) Pattern problems of practice teaching}

Automotive manufacturing technology practice teaching system has not been fully established and is not complete. The practice teaching content is obsolete, and the form is simple. The practice teaching content is single. The entire practice teaching is the mechanical processing technology content, almost without other content. Practice teaching structure mode is not reasonable and the whole process only considers the practice teaching of automobile manufacturing process, which is not consider the comprehensive of practice teaching.

\section{3) Problems of practice base}

Vehicle engineering is a popular major, with a large number of students in each university. Compared with the previous, practice bases are obviously insufficient. On the other hand, most students hope to visit the high tech enterprises which are foreign-funded enterprises or joint ventures, but they have no obligation and are not willing to accept the student to practice. Many units cannot get profits from accepting student practice, and they think that student will affect the production process because of the heavy production schedules, the units also worry about the occurrence of safety accidents. Therefore, factories are not willing to accept students' practice, believing the less trouble the better. For these reasons, the number of enterprises that can carry on the comprehensive practice is limited, and the contradiction between the increase of students' practice demand and the decrease of the practice base will exist.

\section{4) Other problems}

In the practice process, it also exist some other problems. First of all, due to the funding constraints, the limited funds can only cope with the internship fees, and other aspects of the cost are hard to deal with. Secondly, because of the significant increase of automobile manufacturing automation, modernization of manufacturing equipment, students can see substantial content less and less. Therefore, the practice effect is poor and students' interest weakened. Thirdly, the enterprise has certain confidential system, some technology and knowledge cannot be revealed, so the enthusiasm of students' practice is damaged. Last but not limit, the practical teaching staff is not perfect, et al.

\section{BAsic IDEA OF AUtOMOBILE MANUfACTURING TECHNOLOGY PRACTICAL TEACHING INNOVATION [4]}

The objective of the innovation of automobile manufacturing technology practical teaching is enhancing improvement and efficiency. We should make a research on what types of practical teaching model can keep up with the pace of age from many perspectives of practice teaching, aiming to improve efficiency and bring better results.

\section{A. Updating concepts, and valuing automobile manufacturing technology practical teaching}

High engineering colleges tend to put more emphasis on theory (especially in English and Computer) than practice, this phenomenon waste lots of valuable study time and virtually compress students' practice environment, directly leading to students' weak competitive
Advantages in jobs. Apart from this, the section of automobile manufacturing technology practical teaching is more of a formality in the situation of job environment and the craze for graduate school. Launching a discussion on the importance and necessity of practice teaching is to make students and teachers aware that we must change the wrong concepts completely which put more emphasis on theory than practice, value more classroom teaching than practice teaching, and value more knowledge impartment than ability training. If we really pay attention to practical teaching work, we must change the previous concept.

\section{B. Strengthening the relationship between enterprises and university, and establishing a stable practice teaching base[5]}

Relying on university's advantages in theory, scientific research and information, we can establish a regular relationship with the enterprise; especially strengthen contacts with those enterprises where graduates work and actively carrying out technical cooperation or doing joint technical research. If conditions become ripe, enterprises can develop into relatively stable production practice base, which is beneficial to guaranteeing the quality of practice teaching. Changan Group Corporation is the vehicle engineering and thermal energy and power engineering in recent years more stable production practice base. The enterprise's equipment and production technology is more advanced, high degree of automation, strict management, living facilities are relatively complete, is a more ideal practice base. In the internship before we will contact with the relevant departments in the enterprise, internship content, planning, arrangement, life and other issues to communicate. In this way, our production practice can be successfully completed in accordance with the requirements of the teaching plan. Only a more stable practice base is not enough, should be through multiple channels and a variety of ways, when the conditions are ripe to establish more and more stable practice base.

\section{Establishing" 1+1+1"practice teaching model}

Automobile manufacturing technology practical teaching lasts 3 weeks in total. The ' $1+1+1$ ' practice teaching model including 3 parts: During the first week, teachers guide students to internship so that they can consolidate and confirm the theoretical knowledge. During the second week, technician in the factory guide students to carry out Internship and make students familiar with the knowledge of machine parts and assembly process of product. During the last week, the front line worker led students to practice and be familiar with equipment and the operation method.

\section{Establishing a more perfect automobile manufacturing technology practical teaching staff}

In the process of intensifying innovative practice teaching, teachers are organizer and executor. Therefore, it is necessary to intensify the construction of practical teaching staff. The constructions of practice teaching staff level, structure, and scientific number; reasonable to meet the normal operation of teaching should be established. Teachers with master degree or above and with senior professional titles should occupy a 
certain proportion. We should encourage professor senior teacher and Doctoral teacher to take part in the innovation and work of practice teaching. The construction of teaching staff including the following parts. Firstly, organizing youthful teacher to attend training of professional knowledge and skills is a good way for youthful teacher to build up a correct occupation view and to be equipped with good professional ethics and skills. Secondly, engaging professors who have strong practical ability and high level of theory in famous university as part-time professor. Make regular lecture for teachers so that improve youthful teachers' level of practice teaching and theory. Thirdly, creating opportunity for teachers to exercise in relevant apartments, companies, enterprises, providing a platform where teachers can do scientific research and social investigation research. Fourthly, creating opportunities for teachers' further study, and providing convenience for teachers to update the knowledge and to learn of and absorb latest scientific research achievements, which is beneficial to school /teachers and students. Fifthly, engaging suitable company and professors with strong practical ability as practice guidance teachers improves teaching effect

\section{E. Consider practice teaching of automobile manufacturing technology starting from the trinity [6]}

By using the concept of 'concordance' or 'integration' to reestablish the content and structure of automobile manufacturing practice teaching. Practice teaching content of car manufacturing practice innovation includes: making full use of the internship phase of the favorable conditions, making a change of the automobile manufacturing practice from single for automobile manufacturing to a model of trinity which contents automobile manufacturing, preparation for curriculum design, detailed understanding of automobile development and sales, reintegration the process of practice teaching in relation to cars manufacturing. During the period of production practice, more attention should be paid to manufacturing practice, with a supplement of curriculum design preparation, detailed understanding of sales practices in the development and sales. Automobile manufacturing practice contents include mechanical processing technology of typical parts and automobile with engine assembly. Preparation of curriculum design content is to make sure the curriculum design topic, which can be confirmed by themselves as well as appointed by teachers, according to automobile manufacturing practice. Car development and car sales content includes inviting enterprise related technicians or experts do the project report which helps the students make a full understand of the situation and development of car technology as well as the sales process.

\section{F. Establishing perfect practice teaching evaluation system}

Innovating and perfecting check method and evaluation standard of students practice teaching, mainly by checking operational ability, comprehensive analysis ability and innovation ability. Establishing and perfecting independent evaluation system of practice teaching ensure reliability of teaching effect, by checking comprehensive evaluation about teaching system and content, style of teaching and study, management as well as condition and so on. Establishing experts' supervision and inspection system are also useful ways, as well as checking and evaluating students' work regularly and irregularly using oral examination.

\section{CONCLUSION}

As for Automobile manufacturing process practice teaching, to normalize relative processes and innovate the content and manufacture, integrate practice, course design, automobile development and sale into one part. Taking such model of teaching can be very helpful to practical teaching, which is benefit to improving efficiency of teaching, and helps to train comprehensive graduates who have ability to innovate and practice on some projects.

\section{REFERENCES}

[1] Jun Yang Qian He Zhenghua Li "Embedded Curriculum Practice Teaching Reform and Practice” [J] Education pp:37-38 August 2015.

[2] LI Li "Practical Teaching Reform and Innovative Practical Ability Analysis of Mechanical Engineering Specialty” [J] Industry pp:136-137 June 2014.

[3] Zhi Huang "Practice Teaching Reform of Maritime Technology Specialty Based on Excellence Program"[J] Maritime Education Research pp:4-7 February 2016

[4] Liyan Zhang Xiaonan Zeng "Research and Practice of Practical Teaching Reform-

[5] Taking Human Resources Management Course as an Example"[J] Education Science pp:192-193 March 2016

[6] Guomai Liu Yiqun Tan "Strengthening the Construction of Practice Base and Deepening the Reform of Practical Teaching”[J] Research and Exploration in Laboratory pp:132-133 April 2002

[6] Ping Sun "Discussion on Practice Teaching Reform of Undergraduate Course in Building Electrical and Intelligent Specialty"[J] Journal of Jilin Province Economic Management Cadre College pp:109-112 